A WORLD OF EMPIRES 



\section{A WORLD OF EMPIRES}

The Russian Voyage of the Frigate Pallada

Edyta M. Bojanowska

$\longrightarrow$

THE BELKNAP PRESS OF

HARVARD UNIVERSITY PRESS

Cambridge, Massachusetts

London, England 2018 
Copyright (C) 2018 by the President and Fellows of Harvard College All rights reserved

Printed in the United States of America

First printing

\section{Library of Congress Cataloging-in-Publication Data}

Names: Bojanowska, Edyta M., author.

Title: A world of empires : the Russian voyage of the frigate

Pallada / Edyta M. Bojanowska.

Description: Cambridge, Massachusetts : The Belknap Press of Harvard University

Press, 2018. | Includes bibliographical references and index.

Identifiers: LCCN 2017045047 | ISBN 9780674976405 (alk. paper)

Subjects: LCSH: Goncharov, Ivan Aleksandrovich, 1812-1891. Fregat "Pallada." |

Goncharov, Ivan Aleksandrovich, 1812-1891-Criticism and interpretation. |

Pallada (Ship) | Voyages and travels. | Russia-Foreign relations-1801-1917.

Classification: LCC G490 .B7255 2018 | DDC 910.4/5-dc23

LC record available at https://lccn.loc.gov/2017045047

Jacket image: Pallada in Nagasaki, 1854 .

Jacket design: Lisa Roberts 